\title{
Applicability of 3D-CT facial reconstruction for forensic individual identification
}

\section{Aplicabilidade da reconstrução facial em 3D-TC para identificação individual forense}

Sara dos Santos Rocha*

Dalton Luiz de Paula Ramos**

Marcelo de Gusmão Paraíso Cavalcanti***

\begin{abstract}
Computed tomography $(\mathrm{CT})$ is used in several clinical dentistry applications even by axial slices and two and three-dimensional reconstructed images (2D-CT and 3D-CT). The purpose of the current study is to assess the precision of linear measurements made in 3D-CT using craniometric patterns for individual identification in Forensic Dentistry. Five cadaver heads were submitted to a spiral computed tomography using axial slices, and 3D-CT reconstructions were obtained by volume rendering technique with computer graphics tools. Ten (10) craniometric measurements were determined in 3D-CT images by two examiners independently, twice each, and the standard error of intra- and inter-examiner measurements was assessed. The results demonstrated a low standard error of those measurements, from $0.85 \%$ to $3.09 \%$. In conclusion, the linear measurements obtained in osseous and soft tissue structures were considered to be precise in 3D-CT with high imaging quality and resolution.
\end{abstract}

DESCRIPTORS: Tomography, X-ray computed; Skull; Forensic anthropology.

\begin{abstract}
RESUMO: A tomografia computadorizada (TC) tem sido utilizada em diversas áreas clínicas da Odontologia; utilizam-se tanto seus cortes originais quanto as reconstruções em duas e três dimensões (2D-TC e 3D-TC). O presente estudo propõe avaliar a precisão das medidas lineares realizadas na 3D-TC, utilizando a craniometria, para fins de identificação individual na Odontologia Forense. Cinco cabeças de cadáveres foram submetidas a tomografia computadorizada em espiral por meio de cortes axiais e reconstruções em 3D-TC foram obtidas por meio da técnica de volume, utilizando recursos da computação gráfica. Medidas craniométricas $(n=10)$ foram determinadas nas imagens em 3D-TC por dois examinadores independentemente, duas vezes cada um, e uma análise de erro padrão percentual das medidas intra- e inter-examinadores foi realizada. Os resultados demonstraram um erro padrão percentual baixo apresentado por essas medidas, variando entre 0,85\% e 3,09\%. Em conclusão, as medidas lineares obtidas nas estruturas ósseas e tegumentares foram consideradas precisas em 3D-TC, com alta qualidade e resolução de imagem. DESCRITORES: Tomografia computadorizada por raios X; Crânio; Antropologia forense.
\end{abstract}

\section{INTRODUCTION}

The study of anthropometric characteristics is of fundamental importance to solve problems related to identification. Craniometric features are included among these characteristics which are closely connected to forensic dentistry, since they can be used to aid in identifying an individual from a skull, found detached from its skeleton ${ }^{12}$.

Craniometric analysis is performed by locating the anthropometric points and determining the anthropometric measurements, which have already been established in the literature and subdivided into specific studies and can usually be obtained by simple rulers, calipers and other specific tools. ${ }^{6,7,11}$.

The main advantage of computed tomography (CT) is that overlaying structures can be visuali- zed, and less attenuating structures can be distinguished from more attenuating structures. Also the axial and coronal images can be acquired, and the original data can be reformatted based on different views ${ }^{2,3,4,5}$.

Associated to the advances in computer graphics, three-dimensional reconstructed images from CT (3D-CT) have been used in several different clinical applications, as tumor measurements, dental implants planning, evaluation of craniofacial deformities, and for anthropometric studies $^{1,2,3,4,5,8,10,13}$.

Thus, the purpose of this paper is to present an innovative methodology for forensic individual identification, by determining anthropometric measurements using 3D-CT computer graphics resources.

*Graduate student, Forensic Dentistry; **Professor, Department of Social Dentistry; ${ }^{* * *}$ Professor, Department of Radiology - School of Dentistry, University of São Paulo. 
Rocha S dos S, Ramos DL de P, Cavalcanti M de GP. Applicability of 3D-CT facial reconstruction for forensic individual identification.

Pesqui Odontol Bras 2003;17(1):24-8.

\section{MATERIAL AND METHODS}

The study population consisted of five cadaver heads that were scanned in a spiral CT (Toshiba X-Press) for research purposes, with $3 \mathrm{~mm}$ thick axial slices with $2 \mathrm{~mm}$ of reconstruction interval per second of time, 512 x 512 matrix, $120 \mathrm{kVp}$ and

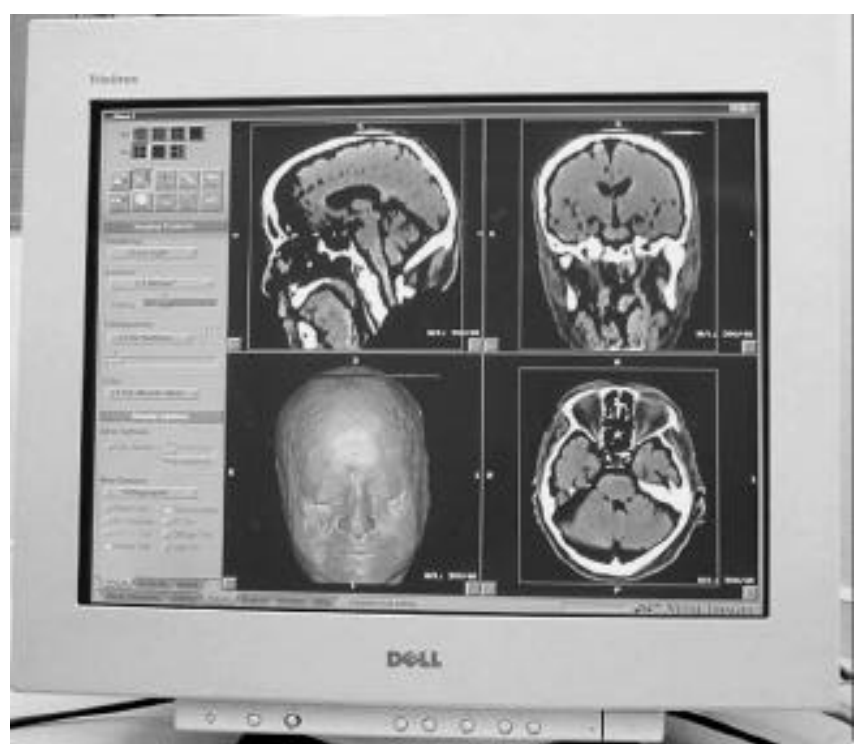

FIGURE 1 - Independent workstation (Dell) using Vitrea ${ }^{\circledR}$ software.

TABLE 1 - Anthropometric points.

\begin{tabular}{c|c|l}
\hline \hline $\mathrm{N}^{\mathrm{o}}$ & Abreviations & \multicolumn{1}{|c}{ Name } \\
\hline 1 & $\mathrm{Al}$ & $\begin{array}{l}\text { Maximum width of nasal } \\
\text { opening }\end{array}$ \\
\hline 2 & $\mathrm{G}$ & $\begin{array}{l}\text { Glabella, most anterior point } \\
\text { of the skull in sagittal plane }\end{array}$ \\
\hline 3 & $\mathrm{M}$ & $\begin{array}{l}\text { Menton, most inferior and ante- } \\
\text { rior point of the mental region }\end{array}$ \\
\hline 4 & $\mathrm{~N}$ & $\begin{array}{l}\text { Nasion, medial point between } \\
\text { the nasofrontal suture and the } \\
\text { nasal origin in midsagittal plane }\end{array}$ \\
\hline 5 & $\mathrm{Ns}$ & $\begin{array}{l}\text { Nasospinale, highest point on } \\
\text { nasal spine }\end{array}$ \\
\hline 7 & $\mathrm{Op}$ & $\begin{array}{l}\text { Opisthocranion, most anterior } \\
\text { part of skull in midsagittal } \\
\text { plane }\end{array}$ \\
\hline 8 & Po & $\begin{array}{l}\text { Porion, highest point of supe- } \\
\text { rior border of the internal } \\
\text { auditory canal }\end{array}$ \\
\hline \hline
\end{tabular}

$100 \mathrm{~mA}$. The original $\mathrm{CT}$ data were stored in a CD-ROM and transferred to an independent workstation (Dell 420 Precision, with Windows NT) using a Vitrea 2.3 version volumetric visualization software (Vital Images Inc., Plymouth, MN, USA) (Figure 1). Multiplanar (coronal and sagittal) and 3D reconstruction of the bone and tegumentar protocols were obtained simultaneously, based on the original axial slices.

The anthropometric points (Table 1) were located and the correspondent measurements (Table 2) were determined electronically by two observers twice each, independently, using the computer software tools (Figures 2, 3, 4 and 5). Visualization, manipulation and analysis were possible using preestablished criteria for bone protocol and soft tissue protocols. Several parameters were used:

1. the side to locate lateral points (left);

2. the standardization of frontal and lateral positions using program functions;

3. the same head position to determine the measurements in the two types of protocols (bone and soft tissue); and

4. the question whether or not a transparency should be used.

Afterwards, a standard error percentage analysis was conducted for the bone and soft tissue measurements - intra- and inter-observers - to test the precision of these measurements.

\section{RESULTS}

Graph 1 shows the quantification of standard error percentage for bone and soft tissue

TABLE 2 - Anthropometric measurements.

\begin{tabular}{c|c|l}
\hline \hline $\mathrm{N}^{\mathbf{o}}$ & Abreviations & \multicolumn{1}{|c}{ Name } \\
\hline 1 & Al-Al & Nasal breadth \\
\hline 2 & G-Op & Skull length \\
\hline 3 & N-M & Facial height \\
\hline 4 & N-Ns & Nasal height \\
\hline 5 & Po-Al & Camper's plane \\
\hline 6 & Po-G & Distance between Po and G \\
\hline 7 & Po-M & Distance between Po and M \\
\hline 8 & Po-N & Distance between Po and N \\
\hline 9 & Po-Ns & Distance between Po and Ns \\
\hline 10 & Zy-Zy & Facial breadth \\
\hline \hline
\end{tabular}


Rocha S dos S, Ramos DL de P, Cavalcanti M de GP. Applicability of 3D-CT facial reconstruction for forensic individual identification. Pesqui Odontol Bras 2003;17(1):24-8.

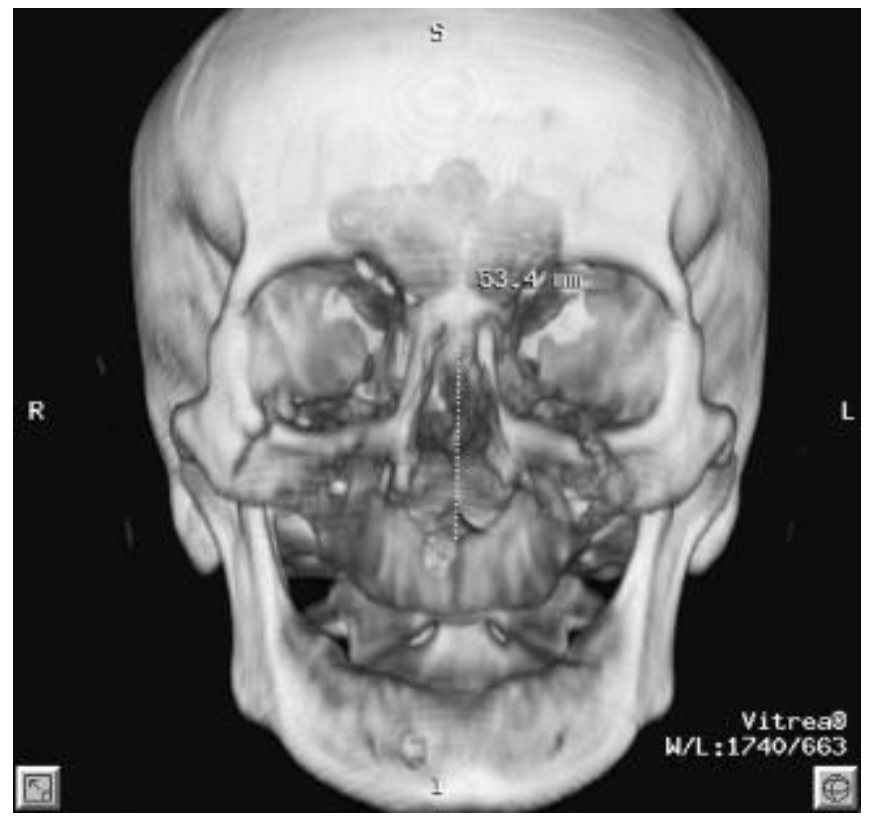

FIGURE 2 - 3D-CT frontal view of a bone measurement: $\mathrm{N}-\mathrm{Ns}(53.4 \mathrm{~mm})$.

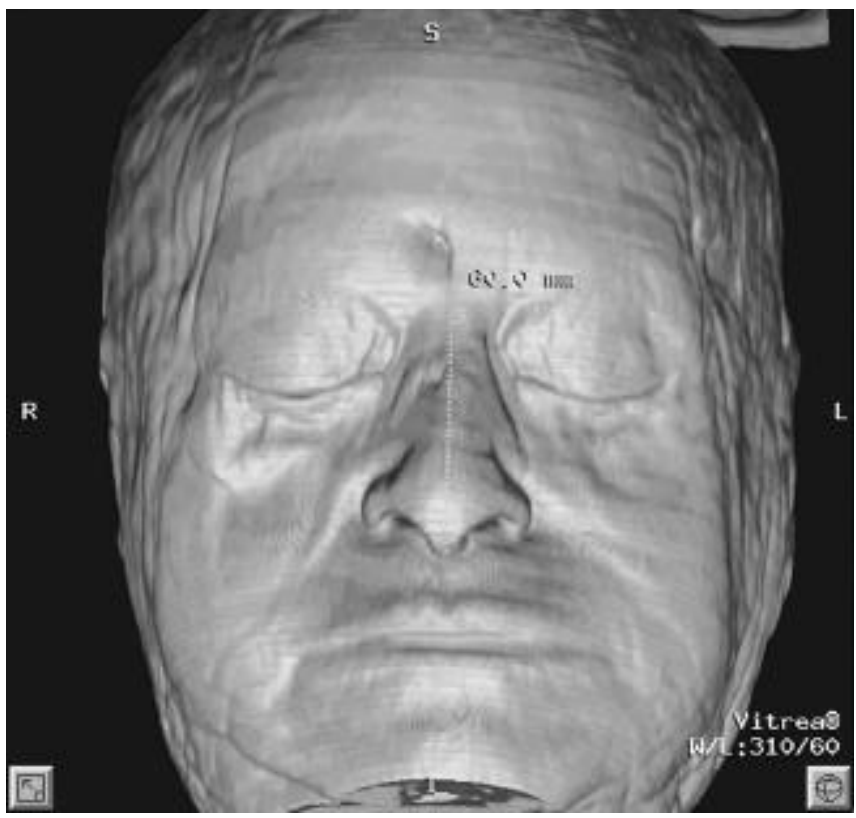

FIGURE 4 - 3D-CT frontal view of a soft tissue measurement: N-Ns $(60.0 \mathrm{~mm})$.

anthropometric measurements, in order to analyze the precision of each observer and to make an interobserver comparison. The standard error percentage in all these evaluations was found to be low, ranging between $0.85 \%$ and $3.09 \%$. The re-

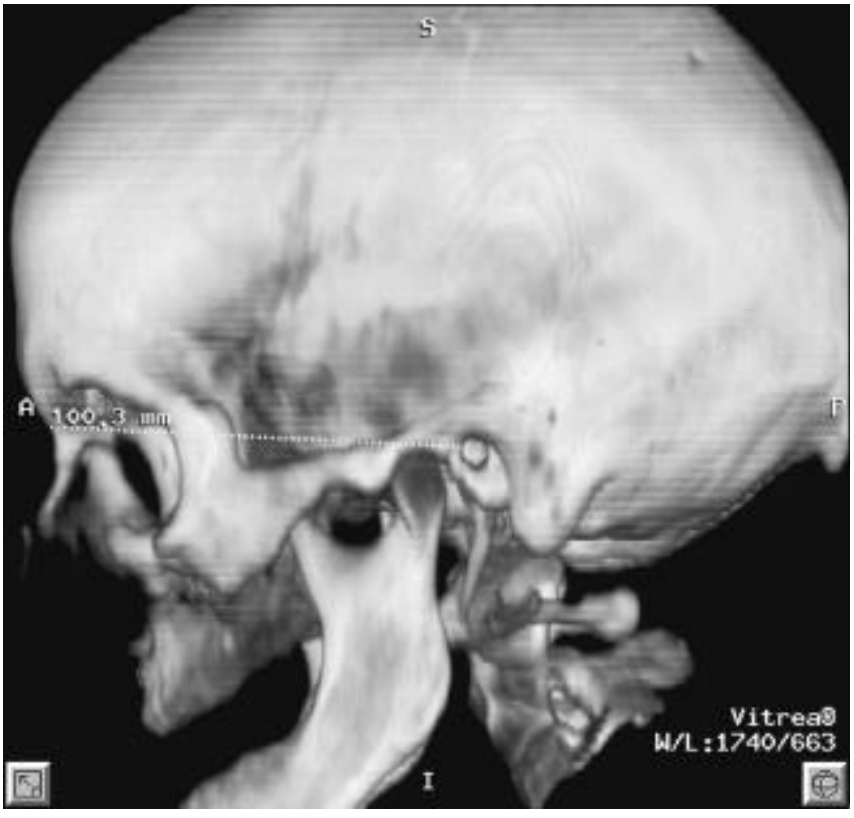

FIGURE 3 - 3D-CT lateral view of a bone measurement: Po-N (100.3 mm).

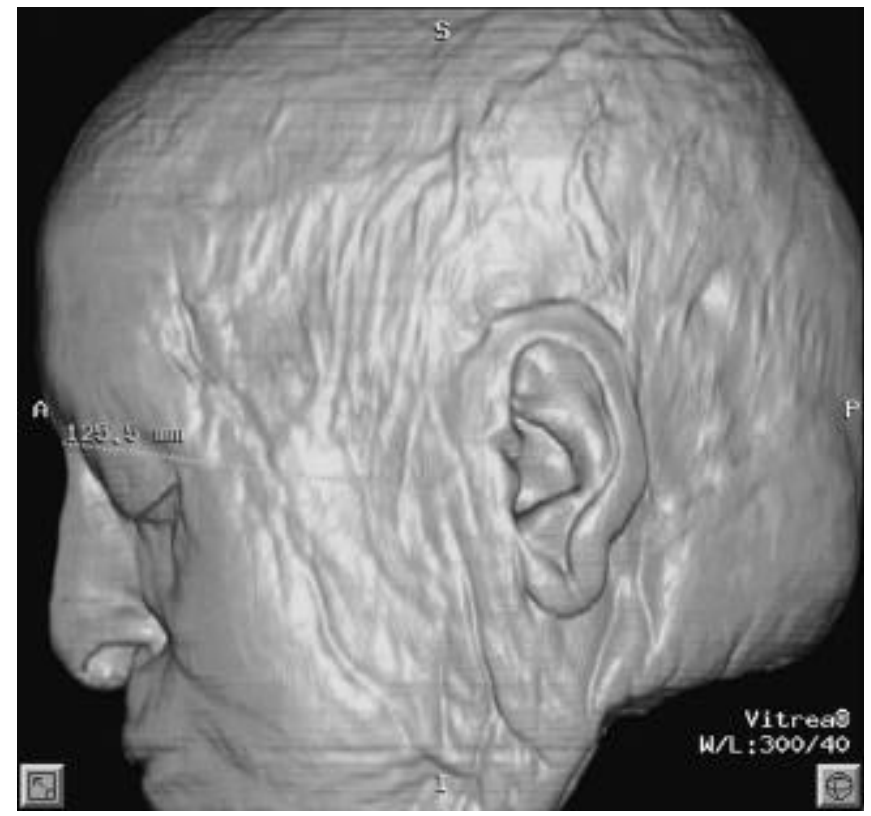

FIGURE 5 - 3D-CT lateral view of a soft tissue measurement: Po-N (125.5 mm).

sults show that the greatest rate of error was found between different bone measurements performed by examiner one, $3.09 \%$, and the least rate of error was that between different soft tissue measurements performed by observer two, $0.85 \%$. The 
Rocha S dos S, Ramos DL de P, Cavalcanti M de GP. Applicability of 3D-CT facial reconstruction for forensic individual identification. Pesqui Odontol Bras 2003;17(1):24-8.

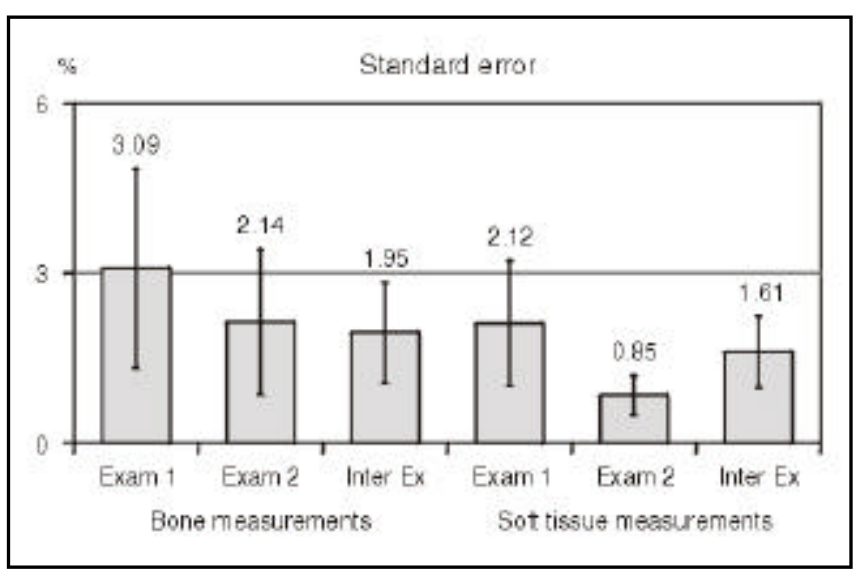

GRAPH 1 - Assessment of standard error of intra- and interobserver $(n=2)$ measurements of bone and soft tissues anatomical points.

measurements of the two observers were compared, and error factors of $1.95 \%$ and $1.61 \%$, respectively, were found in the bone and soft tissue measurements.

\section{DISCUSSION}

Aiming at human identification through craniofacial analysis, and considering that craniometry requires that points can be located with precision and measurements can be determined with accuracy, we suggest that $3 \mathrm{D}-\mathrm{CT}$ is the more reproducible method.

3D-CT imaging has been proven to be more accurate in determining measurements than imaging performed directly on CT slices and 2D-CT image reconstruction ${ }^{3,8}$. Hildelbolt, Vannier ${ }^{10}$, in 1990, performed measurements directly on conventional $\mathrm{CT}$ slices and on $3 \mathrm{D}$ reconstruction, comparing with those performed with a caliper, and stated that 3D-CT measurements were more accurate than those taken from CT slices. Later, in 1998, Cavalcanti, Vannier ${ }^{3}$ validated linear craniofacial measurements in 2D-CT and 3D-CT images using a spiral $\mathrm{CT}$ and comparing them with the correspondent physical measurements. The authors concluded that, in many cases, the linear measurements were considered more accurate in 3D-CT images ${ }^{3}$. In our current research, craniofacial analysis, using a newer computer graphics methodology, offered advantageous features that have shown to be fundamental:

a) Image segmentation. This is very important when internal points must be evaluated ${ }^{13}$. b) Quick manipulation of the image may be required, for example, when determining a measurement by locating one point that is frontal and another that is lateral. The programs used to take up to a few seconds to make a simple rotation ${ }^{9}$.

c) Image quality. It offers excellent color scale and transparency.

d) Evaluation of volume, area, and both linear and angular measurements.

The 3D volume rendering technique was used in our methodology because of its great advantage of being able to assimilate all the information from the original CT slices. Furthermore, it is able to work with a different range of colors and transparencies, and is considered a very refined method for volume rendering of $3 \mathrm{D}$ imaging ${ }^{4}$. The $3 \mathrm{D}$ volume technique used the most modern method available for volume reconstruction and surpassed the 3D surface technique used in earlier work ${ }^{3}$.

In a study to evaluate volume measurements regarding oral tumors using 3D-CT, Cavalcanti, Vannier ${ }^{4}$ stated that the same software allowed direct volume reconstruction, offered better data storage, making it easier to analyze threedimensionally, and to obtain a 3D image of high quality. In our study, we also observed that this program enabled us to locate anthropometric points, even those which could be located only by observing sutures, which was made possible by using transparency scales. Additionally, it was possible to work on the image quickly with rotation and translation movements, to change the zoom view, or even to segment points of interest.

According to the findings, the standard error percentage was adequate for this type of analysis. This is shown in Graph 1, where we observed that the greatest rate of error was $3.09 \%$ for examiner one, in bone measurements, and the least rate of error was $0.85 \%$ for examiner two, in soft tissue measurements.

We believe that the introduction of this methodology and technology represents a great innovation in the field of Forensic Dentistry for human identification, primarily in major urban centers where there is a great concentration of people and where the speed and the objectivity of the method are factors of fundamental importance.

Nonetheless, a study with a greater number of data and with comparisons to physical measure- 
Rocha S dos S, Ramos DL de P, Cavalcanti M de GP. Applicability of 3D-CT facial reconstruction for forensic individual identification.

Pesqui Odontol Bras 2003;17(1):24-8.

ments will be needed to determine the validity (accuracy and precision) of 3D-CT computer graphics forensic individual identification.

\section{CONCLUSIONS}

1. It was possible to establish a qualitative standard for quantitative analysis of 3D-CT images, in bone and soft tissue protocol, with high imaging resolution and processing.

\section{REFERENCES}

1. Arbenz GO. Medicina legal e antropologia forense. Rio de Janeiro: Atheneu; 1988.

2. Cavalcanti MGP, Yang J, Ruprecht A, Vannier MW. Validation of spiral computed tomography for dental implants. Dentomaxillofac Radiol 1998;27:329-33.

3. Cavalcanti MGP, Vannier MW. Quantitative analysis of spiral computed tomography for craniofacial clinical applications. Dentomaxillofac Radiol 1998;27:344-50.

4. Cavalcanti MGP, Vannier MW. Measurement of the volume of oral tumors by three-dimensional spiral computed tomography. Dentomaxillofac Radiol 2000;29:35-40.

5. Cavalcanti MGP. Tomografia computadorizada: reconstruções em 2D e em 3D. In: Freitas A, Rosa EJ, Souza IF. Radiologia odontológica. $5^{\mathrm{a}}$ ed. São Paulo: Artes Médicas; 2000. p.681-726.

6. Cavalcanti MGP, Ruprecht A, Vannier MW. Evaluation of an ossifying fibroma using three-dimensional computed tomography. Dentomaxillofac Radiol 2001;30:342-5.

7. Farkas LG. Anthropometry of the head and face. New York: Raven Press; 1994.

8. Fishman EK, Magid D, Ney DR, Chaney EL, Pizer SM, Rosenman JG, et al. Three-dimensional imaging. Radiology 1991;181:321-37.
2. 3D-CT imaging using the volume rendering technique by computer graphics made it possible to determine the craniofacial measurements with adequate precision.

\section{ACKNOWLEDGEMENTS}

FAPESP, Master's degree - Sara dos Santos Rocha (01/05700-3) - and Grants - (99/10276-4) Professor, Ph.D., Marcelo G. P. Cavalcanti.

9. Hildebolt CF, Vannier MW. Three-dimensional measurement accuracy of skull surface landmarks. Am J Phys Anthropol 1988;76:497-503.

10. Hildebolt CF, Vannier MW, Knapp RH. Validation study of skull three-dimensional computerized tomography measurements. Am J Phys Anthropol 1990;82:283-94.

11. Offutt CJ. Volumetric 3-D imaging of computerized tomography scans. Radiol Technol 1990;61:312-9.

12. Ono I, Ohura T, Narumi E, Kawashima K, Matsuno I, Nakamura $\mathrm{S}$, et al. Three-dimensional analysis of craniofacial bones using three-dimensional computed tomography. J Craniomaxillofac Surg 1992;20:49-60.

13. Ramos DLP. Contribuição ao estudo da aplicação de fotografias de face em perícias de identificação antropológica quando comparadas com telerradiografias frontais [Tese de Doutorado]. São Paulo: Faculdade de Odontologia da USP; 1995.

14. Silva M. Compêndio de Odontologia Legal. São Paulo: MEDSI; 1997.

15. Vannier MW, Conroy GC, Marsh JL, Knapp RH. Three-dimensional cranial surface reconstructions using high-resolution computed tomography. Am J Phys Anthropol 1985;67:299-311. 